\title{
A review of accounting research in internationalising journals in the South African region
}

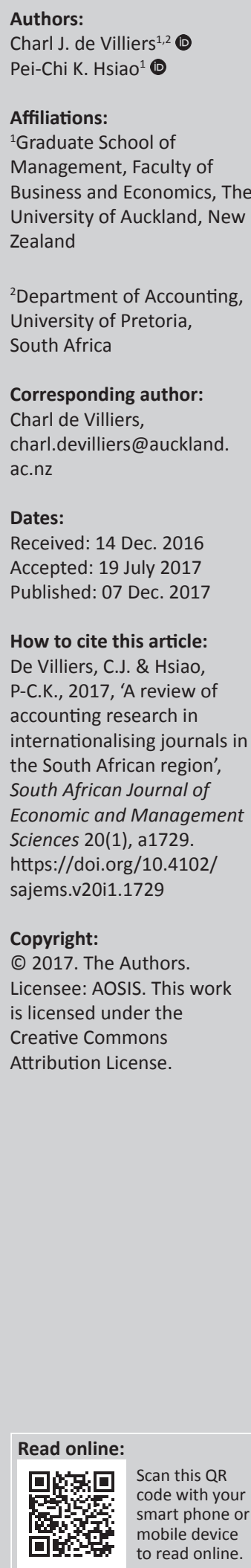

Background: This study analyses the accounting research articles published by South African journals.

Aim and setting: A review of accounting research in internationalising journals in the South African region that publish accounting research.

Methods: The characteristics of accounting articles were analysed. Five journals were analysed, including the four internationalising journals, Investment Analysts Journal, Meditari Accountancy Research, South African Journal of Business Management, and South African Journal of Economic and Management Sciences and one local journal, South African Journal of Accounting Research (SAJAR).

Results: The findings of this study will be of interest to journal editors, authors who would like their research to make an impact and be cited, as well as university research administrators and government higher education policy-makers.

Conclusion: The analyses show that many of the highly cited articles have been published recently, boding well for the citation statistics of these journals in future and indicating some success in their efforts to internationalise. The citations of SAJAR lag behind the citations of the internationalising journals. Each journal publishes articles that cover different subject area(s). Within accounting research, accounting education and social and environmental accounting are popular areas of research, whereas taxation; the public sector; and management accounting are not well represented among published articles during 2015-2016 in these five journals. About half of all accounting articles claim their insights will contribute to the accounting literature, with much smaller percentages claiming to contribute to management, policymaking and practice. The most prolific authors and most prominent universities to some extent follow the most popular subject areas, with a social and environmental researcher, Warren Maroun, featuring strongly, and his university, the University of the Witwatersrand, being prominent. Large proportions of authors of 2015-2016 articles are from outside of Africa, speaking to the success of the internationalisation efforts of the internationalising journals, whereas SAJAR mostly publishes articles by African authors.

\section{Introduction}

The accounting academic community in South Africa is characterised by a teaching focus rather than a research focus (Samkin \& Schneider 2014b; Venter \& de Villiers 2013), which has hindered efforts to link with the international research community. South African accounting academics tend to publish in South African journals. However, universities are increasingly expecting accounting academics to fulfil their research obligations and publish in international journals, which are seen to be better quality compared to local journals (Samkin \& Schneider 2014a). A number of South African journals have started to internationalise their journals by, for instance, aspiring to be included in international journal lists, such as Scopus. This review reflects upon the state of accounting research as exemplified by articles published by internationalising South African journals, contrasted with the premier local accounting journal.

This study assesses South African journals (defined in this study as scientific journals on the South African Department of Higher Education and Training journal list) which publish accounting research (defined in this study as journals that have published at least four accounting articles in 2015 and 2016). While the focus is placed on internationalising journals (defined in this study as being on Scopus), the premier local accounting journal is analysed for a more comprehensive assessment of accounting research and to provide a point of comparison. The four international journals to be identified by following the assessment criteria were Investment 
Analysts Journal (IAJ), Meditari Accountancy Research (MedAR), South African Journal of Business Management (SAJBM) and South African Journal of Economic and Management Sciences (SAJEMS). The local accounting journal, South African Journal of Accounting Research (SAJAR), is assessed because of its status as the premier South African accounting journal among South African accounting academics. An overview of the journals is provided in Appendix 1, which includes the year of first issue, editor, 2015 Scopus citation statistics, overall and 2012 to present h-index, ${ }^{1} 2016$ ABCD rating and current statement of 'Aims and Scope'. It should be noted that, although the focus is on accounting research, these journals publish papers from diverse management fields. $M e d A R$ and $S A J A R$ primarily focus on accounting research, $I A J$ focuses on finance and investments, with $S A J B M$ and SAJEMS having a broader, general business, remit. These differences are also evident from the types of articles published in each journal, which will be discussed in the findings section. An inspection of the journals' h-indexes in Appendix 1 provides an early indication that articles published in the internationalising journals are cited more than articles published in SAJAR.

This study is based on a similar study of accounting research in Asia-Pacific journals (Benson et al. 2015). Following Benson et al. (2015), modified where appropriate, this paper analyses the most cited papers in each of the five journals, as measured by total citations and by citations per year (total citations divided by the number of years since publication). In addition to the characteristics examined by Benson et al. (2015), this study provides an overview of the non-accounting publications, details of what is published in the journals, summarises the relevance to practice of the articles, provides more detail on the research methods applied and summarises the universities that feature prominently in published articles in these journals.

The findings of this study should be of interest to universities in their efforts to manage the research output of their accounting academics, and may also hold policy implications related to government efforts to promote research at universities. In addition, journal editors and authors who are interested in maximising the impact of their research and being cited, will be interested in the findings.

\section{Most frequently cited articles}

Google Scholar data and the ABDC journal rankings were used to measure the impact of accounting articles; this is consistent with studies such as Benson et al. (2015) and Rosenstreich and Wooliscroft (2009). Google Scholar includes all citations in scientific sources, such as journals, books, theses, etc. By contrast, other sources of citation statistics, such as Scopus and Web of Science, limit their citations statistics to references made in the journals on their lists. Google Scholar provides the most comprehensive coverage of scientific publications

1.A journal's $h$-index reflects the number of articles published in the journal (h), which has been cited at least $h$ number of times. Therefore, a higher $h$-index reflects higher overall citations. and is therefore considered appropriate for the purpose of this study. Citation counts were drawn from Google Scholar on 7 July 2017, using the software program Harzing's Publish or Perish. Citations per year for each article are calculated as the total number of citations for the paper divided by (2017 less the year of publication).

Table 1, Panel A, lists the 10 most frequently cited articles, measured by total citations, published in each journal over its history. This is followed by Panel B listing the most frequently cited articles measured by citations per year, measured as total citations divided by number of years since publication. In situations where there is no clear cut-off, all papers with the same number of citations, or citations per year, are included.

$S A J B M$ has the highest mean total citation for their top 10 cited articles, followed by MedAR, SAJEMS and IAJ. Note that $S A J B M$ on 148.80 is far ahead of the three journals in the middle, which are bunched together between 46 and 61, with $S A J A R$ lagging behind on 23

$M e d A R$ has the highest mean citations per year for their top 10 cited articles, followed by SAJBM, SAJEMS, IAJ and finally $S A J A R$. However, it should be noted that the difference between the internationalising journals' averages are relatively small, with $S A J A R$ lagging behind.

Note that many of the most cited papers per year were published in 2015 or later. This may be because these journals are internationalising and therefore their articles are being noticed and cited more frequently of late. If this trend continues, these journals' citation statistics should benefit in future. This is also true for $S A J A R$, but apart from Raemaekers et al. (2016), none of the other papers would have made it onto the list if it was published in one of the other journals.

Table 2 lists the 10 most frequently cited articles published during 2015-2016 for each journal, measured by total number of citations. Where fewer articles are listed for a journal, this is because fewer than ten articles have been cited. Where more than 10 articles are listed for a journal, this is because more than one article has been cited the same number of times around the cut-off of 10 articles.

$\operatorname{Med} A R$ has the highest number of citations for articles published during 2015-2016, with the other journals lagging far behind. As mentioned before, a high level of citations for recent articles bodes well for future citations. It is worth noting that articles published in the journals that do not have 'South African' in their names are cited more often. Journal names may be indicative of their strategic stance towards integration with the international research community and internationalisation strategies may be increasing the attention of the international research community on articles published in journals with an internationalisation strategy. 


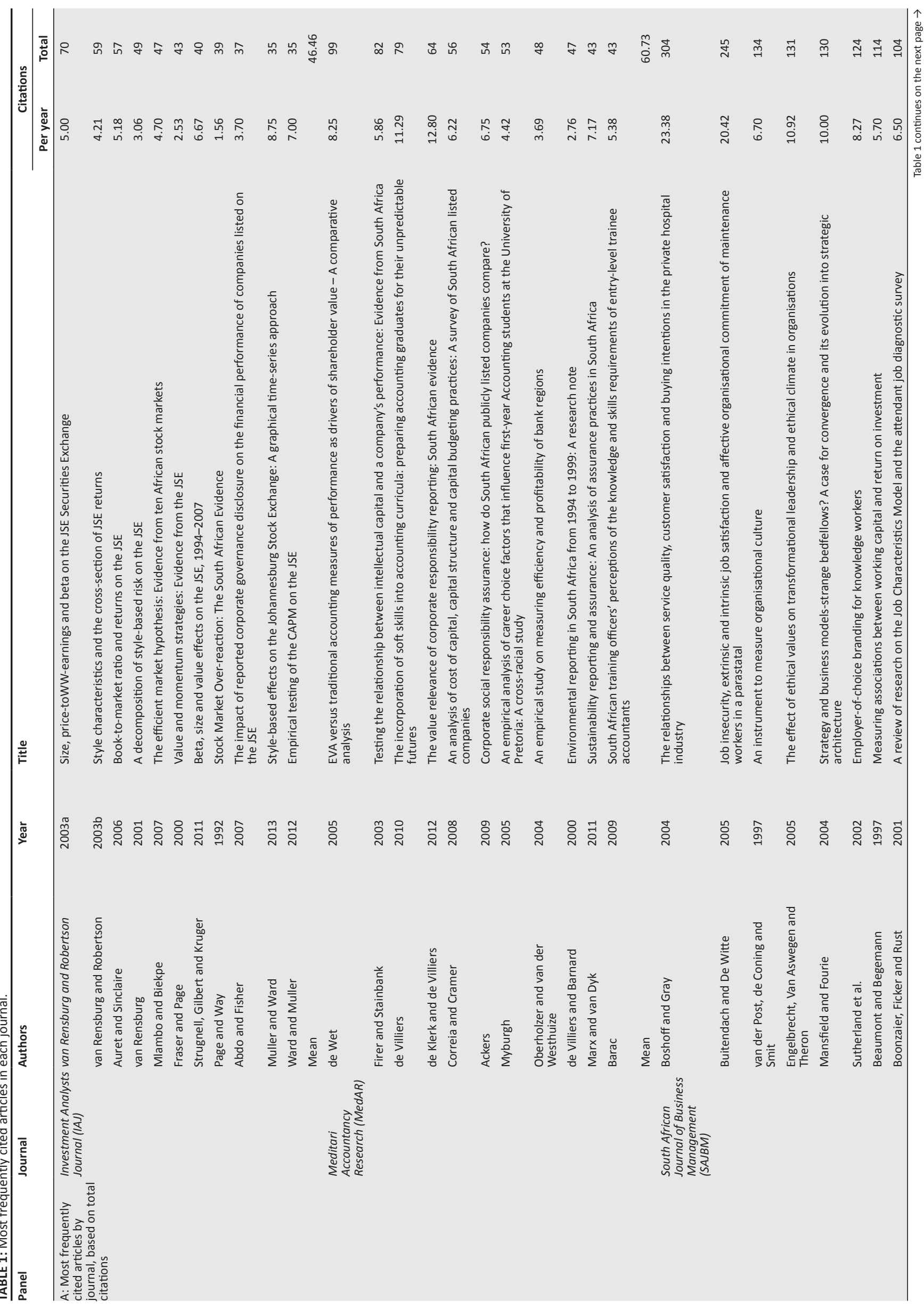




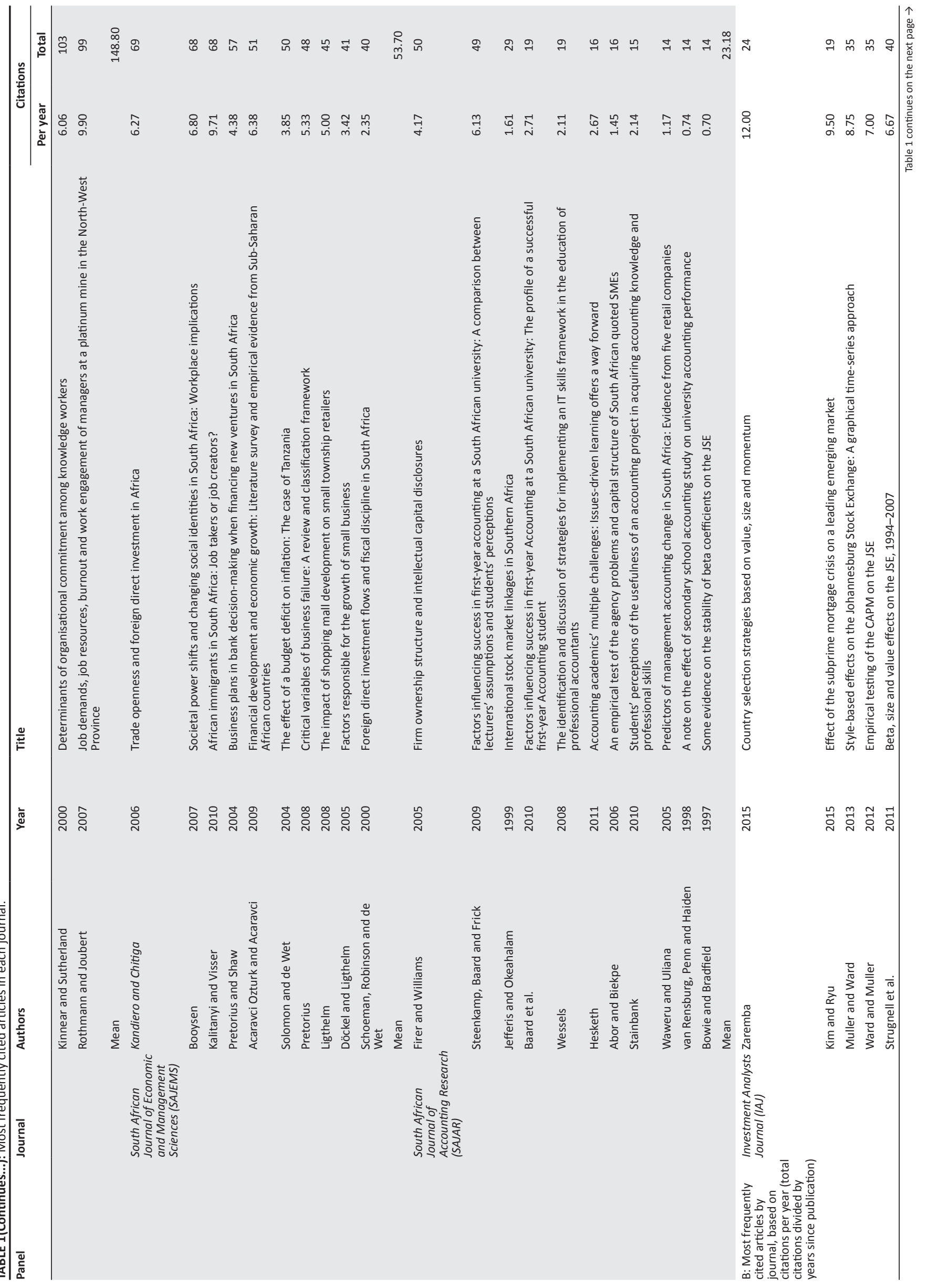




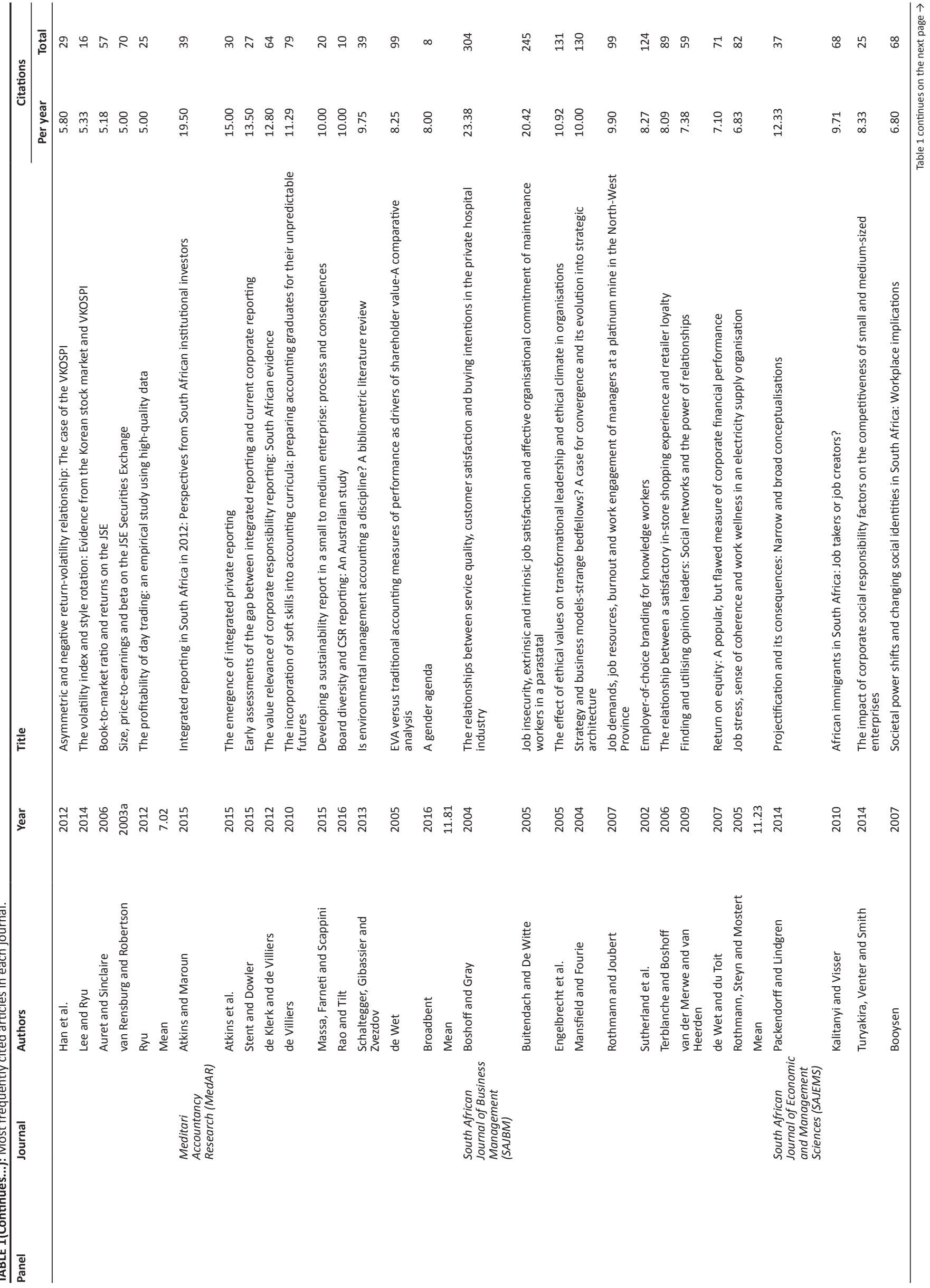




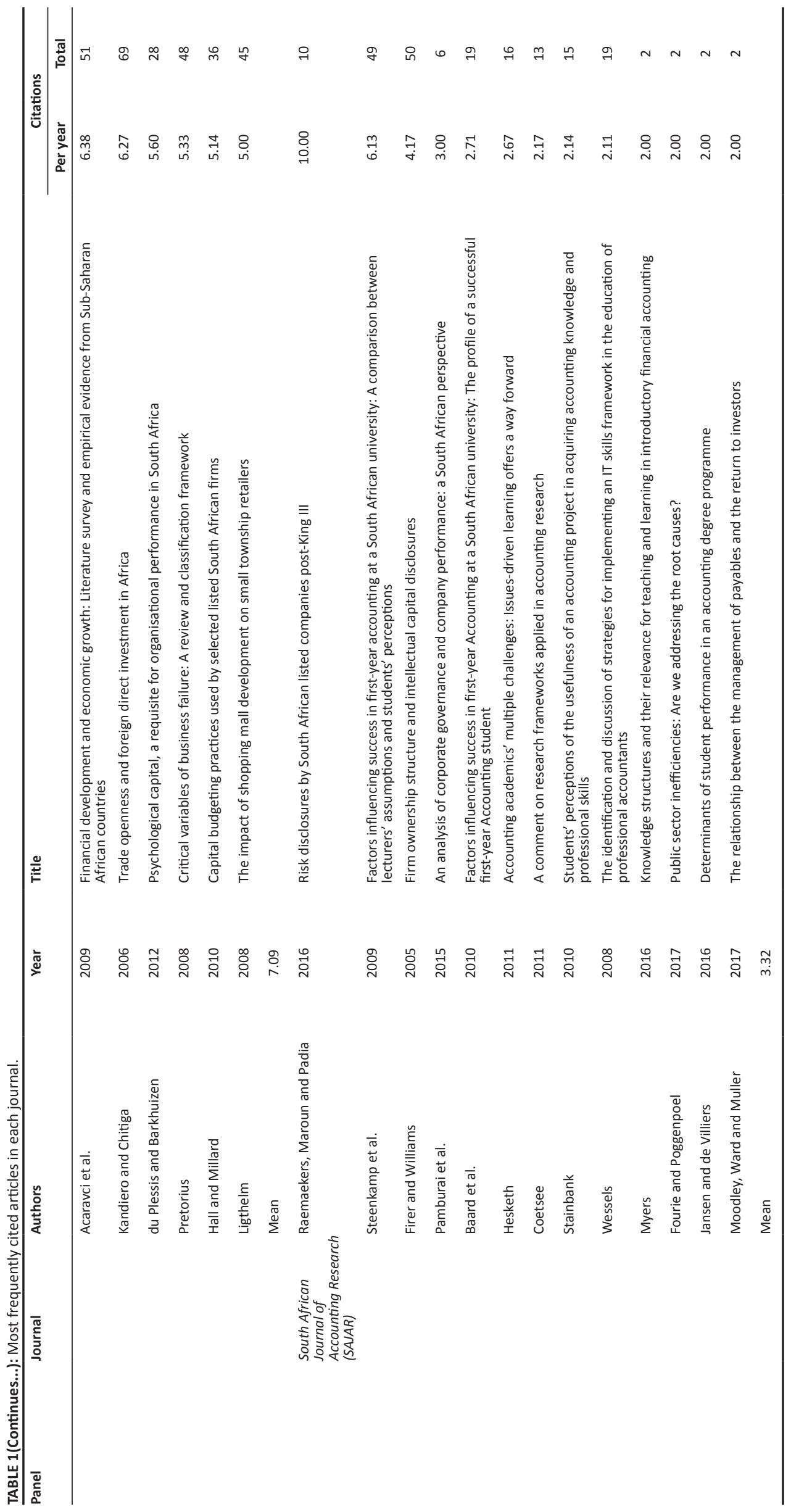


TABLE 2: Most frequently cited articles published in each journal during 2015-2016.

\begin{tabular}{|c|c|c|c|c|}
\hline Journal & Authors & Year & Title & Citations \\
\hline \multirow{11}{*}{$\begin{array}{l}\text { Investment Analysts } \\
\text { Journal (IAJ) }\end{array}$} & Zaremba & 2015 & Country selection strategies based on value, size and momentum & 24 \\
\hline & Kim and Ryu & 2015 & Effect of the subprime mortgage crisis on a leading emerging market & 19 \\
\hline & $\mathrm{Li}$ & 2016 & Endogeneity in CEO power: A survey and experiment & 4 \\
\hline & Fang and Wang & 2015 & Fund manager characteristics and performance & 4 \\
\hline & Katzke and Garbers & 2016 & $\begin{array}{l}\text { Do long memory and asymmetries matter when assessing downside } \\
\text { return risk? }\end{array}$ & 3 \\
\hline & Ryu, Ryu and Hwang & 2016 & $\begin{array}{l}\text { Corporate social responsibility, market competition, and shareholder } \\
\text { wealth }\end{array}$ & 3 \\
\hline & Su, Wan and Feng & 2015 & $\begin{array}{l}\text { Government control structure and allocation of credit: evidence from } \\
\text { government-owned companies in China }\end{array}$ & 3 \\
\hline & Miller and Ward & 2015 & The market impact on shares entering or leaving JSE indices & 2 \\
\hline & Lee and Yao & 2015 & Evaluating and predicting the failure probabilities of hedge funds & 2 \\
\hline & Eom et al. & 2015 & $\begin{array}{l}\text { Effects of the market factor on portfolio diversification: The case of market } \\
\text { crashes }\end{array}$ & 2 \\
\hline & Mean & & & 6.60 \\
\hline \multirow[t]{12}{*}{$\begin{array}{l}\text { Meditari Accountancy } \\
\text { Research (MedAR) }\end{array}$} & Atkins and Maroun & 2015 & $\begin{array}{l}\text { Integrated reporting in South Africa in 2012: Perspectives from South } \\
\text { African institutional investors }\end{array}$ & 39 \\
\hline & Atkins et al. & 2015 & The emergence of integrated private reporting & 30 \\
\hline & Stent and Dowler & 2015 & $\begin{array}{l}\text { Early assessments of the gap between integrated reporting and current } \\
\text { corporate reporting }\end{array}$ & 27 \\
\hline & Massa et al. & 2015 & $\begin{array}{l}\text { Developing a sustainability report in a small to medium enterprise: } \\
\text { process and consequences }\end{array}$ & 20 \\
\hline & Khlif, Hussainey and Achek & 2015 & $\begin{array}{l}\text { The effect of national culture on the association between profitability and } \\
\text { corporate social and environmental disclosure: a meta-analysis }\end{array}$ & 14 \\
\hline & Rao and Tilt & 2016 & Board diversity and CSR reporting: An Australian study & 10 \\
\hline & Broadbent & 2016 & A gender agenda & 8 \\
\hline & Hay & 2015 & The frontiers of auditing research & 8 \\
\hline & Callaghan and Papageorgiou & 2015 & $\begin{array}{l}\text { Gender differences in locus of control and student performance in the } \\
\text { South African context of accounting studies }\end{array}$ & 7 \\
\hline & Parker & 2015 & Accounting historiography: looking back to the future & 7 \\
\hline & Soni, Maroun and Padia & 2015 & $\begin{array}{l}\text { Perceptions of justice as a catalyst for whistle-blowing by trainee auditors } \\
\text { in South Africa }\end{array}$ & 7 \\
\hline & Maroun & $2015 a$ & $\begin{array}{l}\text { Culture, profitability, non-financial reporting and a meta-analysis: } \\
\text { Comments and observations }\end{array}$ & 7 \\
\hline \multirow{12}{*}{$\begin{array}{l}\text { South African Journal of } \\
\text { Business Management } \\
\text { (SAJBM) }\end{array}$} & Chang, Magobe and Kim & 2015 & E-commerce applications in the tourism industry: A Tanzania case study & 5 \\
\hline & Kruger, Saayman and Slabbert & 2015 & $\begin{array}{l}\text { Managing visitors' dining and retail experiences in South African national } \\
\text { parks }\end{array}$ & 5 \\
\hline & Botha, van Vuuren and Kunene & 2015 & $\begin{array}{l}\text { An integrated entrepreneurial performance model focusing on the } \\
\text { importance and proficiency of competencies for start-up and established } \\
\text { SMEs }\end{array}$ & 5 \\
\hline & Jonck and Swanepoel & 2015 & $\begin{array}{l}\text { Exploring the theoretical link between cultural and emotional intelligence: } \\
\text { A system analysis for human resource management }\end{array}$ & 4 \\
\hline & Naidoo and Sutherland & 2016 & $\begin{array}{l}\text { A management dilemma: Positioning employees for internal competition } \\
\text { versus internal collaboration. Is coopetition possible? }\end{array}$ & 3 \\
\hline & Saayman and Dieske & 2015 & Segmentation by motivation of tourists to the Kgalagadi Transfrontier Park & 3 \\
\hline & Sutherland et al. & 2015 & $\begin{array}{l}\text { The components of career capital and how they are acquired by } \\
\text { knowledge workers across different industries }\end{array}$ & 3 \\
\hline & Al-Jabri & 2015 & The intention to use mobile banking: Further evidence from Saudi Arabia & 3 \\
\hline & Kruger and Mostert & 2015 & $\begin{array}{l}\text { The influence of cell phone users' relationship intentions on expectations } \\
\text { and perceptions of service recovery' }\end{array}$ & 2 \\
\hline & Lee, Chao and Chen & 2015 & $\begin{array}{l}\text { The relationship between HRM practices and the service performance of } \\
\text { student interns: Industry perspective }\end{array}$ & 2 \\
\hline & Wesson, Bruwer and Hamman & 2015 & $\begin{array}{l}\text { Share repurchase and dividend payout behaviour: The South African } \\
\text { experience }\end{array}$ & 2 \\
\hline & Mean & & & 3.36 \\
\hline \multirow{7}{*}{$\begin{array}{l}\text { South African Journal of } \\
\text { Economic and Management } \\
\text { Sciences (SAJEMS) }\end{array}$} & Sethibe and Steyn & 2015 & $\begin{array}{l}\text { The relationship between leadership styles, innovation and organisational } \\
\text { performance: A systematic review }\end{array}$ & 6 \\
\hline & Harris and Vermaak & 2015 & $\begin{array}{l}\text { Economic inequality as a source of interpersonal violence: Evidence from } \\
\text { Sub-Saharan Africa and South Africa }\end{array}$ & 5 \\
\hline & Ngulube and Ngulube & 2015 & $\begin{array}{l}\text { Mixed methods research in The South African Journal of Economic and } \\
\text { Management Sciences: An investigation of trends in the literature }\end{array}$ & 5 \\
\hline & Marcia, Callaghan and Maroun & 2015 & $\begin{array}{l}\text { Value relevance and corporate responsibility reporting in the South } \\
\text { African context: An alternate view post-King III }\end{array}$ & 4 \\
\hline & Bussin & 2015 & CEO pay-performance sensitivity in the South African context & 4 \\
\hline & Özer et al. & 2015 & $\begin{array}{l}\text { Effects of intellectual capital on qualitative and quantitative performance: } \\
\text { Evidence from Turkey }\end{array}$ & 4 \\
\hline & Taljaard, Ward and Muller & 2015 & $\begin{array}{l}\text { Board diversity and financial performance: A graphical time-series } \\
\text { approach }\end{array}$ & 3 \\
\hline
\end{tabular}


TABLE 2(Continues...): Most frequently cited articles published in each journal during 2015-2016.

\begin{tabular}{|c|c|c|c|c|}
\hline Journal & Authors & Year & Title & Citations \\
\hline & Hill and Maroun & 2015 & $\begin{array}{l}\text { Assessing the potential impact of the Marikana incident on South African } \\
\text { mining companies: An event method study }\end{array}$ & 3 \\
\hline & Coetzee & 2015 & $\begin{array}{l}\text { The perceived treatment of employees from designated groups in the } \\
\text { workplace }\end{array}$ & 3 \\
\hline & Burra et al. & 2015 & $\begin{array}{l}\text { Implementing the countercyclical capital buffer in South Africa: Practical } \\
\text { considerations }\end{array}$ & 3 \\
\hline & Mean & & & 4.00 \\
\hline \multirow{9}{*}{$\begin{array}{l}\text { South African Journal of } \\
\text { Accounting Research (SAJAR) }\end{array}$} & Raemaekers et al. & 2016 & Risk disclosures by South African listed companies post-King III & 10 \\
\hline & Pamburai et al. & 2015 & $\begin{array}{l}\text { An analysis of corporate governance and company performance: a South } \\
\text { African perspective }\end{array}$ & 6 \\
\hline & Myers & 2016 & $\begin{array}{l}\text { Knowledge structures and their relevance for teaching and learning in } \\
\text { introductory financial accounting }\end{array}$ & 2 \\
\hline & Jansen and de Villiers & 2016 & $\begin{array}{l}\text { Determinants of student performance in an accounting degree } \\
\text { programme }\end{array}$ & 2 \\
\hline & Scholtz and Smit & 2015 & $\begin{array}{l}\text { Factors influencing corporate governance disclosure of companies listed } \\
\text { on the Alternative Exchange (AltX) in South Africa }\end{array}$ & 3 \\
\hline & Loliwe & 2016 & $\begin{array}{l}\text { Voluntary employee reporting by the wholesale and retail companies } \\
\text { listed on the Johannesburg Stock Exchange }\end{array}$ & 1 \\
\hline & Eloff and de Villiers & 2015 & The value relevance of goodwill reported under IFRS 3 versus IAS 22 & 1 \\
\hline & Dhai & 2015 & $\begin{array}{l}\text { A comparison of the performance of the FTSE South Africa Islamic Index to } \\
\text { the conventional market (JSE) in South Africa }\end{array}$ & 1 \\
\hline & Mean & & & 3.00 \\
\hline
\end{tabular}

TABLE 3: Management field of articles published during the period 2015-2016.

\begin{tabular}{|c|c|c|c|c|c|c|c|}
\hline \multirow[t]{2}{*}{ Subject area } & \multicolumn{5}{|c|}{ Journals } & \multirow[t]{2}{*}{ Total $(n)$} & \multirow[t]{2}{*}{$\%$} \\
\hline & IAJ & MedAR & SAJBM & SAJEMS & SAJAR & & \\
\hline Accounting & 4 & 42 & 5 & 9 & 16 & 76 & 34.55 \\
\hline Economics & 3 & 1 & 5 & 31 & 0 & 40 & 18.18 \\
\hline Finance & 24 & 0 & 5 & 8 & 4 & 41 & 18.64 \\
\hline Management & 0 & 0 & 23 & 15 & 0 & 38 & 17.27 \\
\hline Other & 0 & 1 & 19 & 5 & 0 & 25 & 11.36 \\
\hline Total & 31 & 44 & 57 & 68 & 20 & 220 & 100.00 \\
\hline
\end{tabular}

IAJ, Investment Analysts Journal; MedAR, Meditari Accountancy Research; SAJBM, South African Journal of Business Management; SAJEMS, South African Journal of Economic and Management Sciences; SAJAR, South African Journal of Accounting Research.

\section{Analysis of recent accounting publications \\ Relative role of accounting research}

All papers published during 2015-2016, within the five journals were classified into a management field. Multidisciplinary studies were categorised according to their dominant focus, which results in papers being classified under a single category. The classification is based on the keywords listed by the author(s), the stated purpose of the paper, the references cited and the academic department of the author(s).

Table 3 shows the subject area of articles published in each journal during 2015-2016.

Among these five journals, the main sources of accounting research are MedAR and $S A J A R$. Each journal has a unique focus in terms of subject area(s), based on articles published during 2015-2016, with IAJ being finance oriented, MedAR and SAJAR accounting, SAJBM management and SAJEMS being economics and management oriented. MedAR and $S A J A R$ are most focused on accounting, as can be expected from the inclusion of the word 'accounting/accountancy' in these journals' titles and the emphasis on accounting research in their stated objectives.
Table 4 shows the accounting research (2015-2016) classified according to ScholarOne manuscript submission categories.

As can be expected for refereed journals, research paper is the most common classification.

\section{Research areas in accounting}

Table 5 documents the major topic areas covered within the accounting research published in the five journals during 2015-2016. The topic categories follow Benson et al. (2015) in using the 10 European Accounting Association (EAA) topic areas: auditing (AU), accounting education (ED), financial analysis (FA), financial reporting (FR), governance (GV), accounting and information systems (IS), management accounting (MA), public sector accounting (PS), social and environmental (SE), taxation (TX), and an additional category, Other, for studies not captured in the EAA categories.

AU includes any article related to auditing and assurance, for example, auditors, audit reports, and audit fees. ED covers any educational aspects of accounting, for example, universities, accounting students, and accounting curriculum. FA relates to users and analysis of financial accounting information, e.g. analyst forecast, value 
TABLE 4: Article classifications of accounting articles 2015-2016.

\begin{tabular}{|c|c|c|c|c|c|c|c|}
\hline \multirow{2}{*}{$\begin{array}{l}\text { ScholarOne } \\
\text { classification }\end{array}$} & \multicolumn{5}{|c|}{ Journals } & \multirow[t]{2}{*}{ Total $(n)$} & \multirow[t]{2}{*}{$\%$} \\
\hline & IAJ & MedAR & SAJBM & SAJEMS & SAJAR & & \\
\hline Case study & 0 & 2 & 0 & 0 & 0 & 2 & 2.63 \\
\hline Conceptual paper & 0 & 1 & 0 & 2 & 1 & 4 & 5.26 \\
\hline General review & 0 & 5 & 0 & 0 & 0 & 5 & 6.58 \\
\hline Literature review & 0 & 3 & 0 & 0 & 0 & 3 & 3.95 \\
\hline Research paper & 4 & 28 & 5 & 7 & 15 & 59 & 77.63 \\
\hline Technical paper & 0 & 0 & 0 & 0 & 0 & 0 & 0.00 \\
\hline Viewpoint & 0 & 3 & 0 & 0 & 0 & 3 & 3.95 \\
\hline Total & 4 & 42 & 5 & 9 & 16 & 76 & 100.00 \\
\hline
\end{tabular}

IAJ, Investment Analysts Journal; MedAR, Meditari Accountancy Research; SAJBM, South African Journal of Business Management; SAJEMS, South African Journal of Economic and Management Sciences; SAJAR, South African Journal of Accounting Research.

TABLE 5: Articles by EAA categories: 2015-2016 articles.

\begin{tabular}{|c|c|c|c|c|c|c|c|}
\hline \multirow[t]{2}{*}{ EAA Categories } & \multicolumn{5}{|c|}{ Journals } & \multirow[t]{2}{*}{ Total $(n)$} & \multirow[t]{2}{*}{$\%$} \\
\hline & IAJ & MedAR & SAJBM & SAJEMS & SAJAR & & \\
\hline Accounting and Information Systems (IS) & 0 & 0 & 0 & 1 & 0 & 1 & 1.32 \\
\hline Accounting Education (ED) & 0 & 11 & 0 & 0 & 4 & 15 & 19.74 \\
\hline Auditing (AU) & 0 & 2 & 0 & 0 & 1 & 3 & 3.95 \\
\hline Financial Analysis (FA) & 4 & 2 & 1 & 3 & 2 & 12 & 15.79 \\
\hline Financial Reporting (FR) & 0 & 1 & 0 & 2 & 2 & 5 & 6.58 \\
\hline Governance (GV) & 0 & 2 & 1 & 1 & 3 & 7 & 9.21 \\
\hline Management Accounting (MA) & 0 & 1 & 1 & 0 & 0 & 2 & 2.63 \\
\hline Public Sector Accounting (PS) & 0 & 0 & 0 & 0 & 0 & 0 & 0.00 \\
\hline Social and Environmental (SE) & 0 & 10 & 1 & 1 & 1 & 13 & 17.11 \\
\hline Taxation (TX) & 0 & 0 & 0 & 0 & 2 & 2 & 2.63 \\
\hline Other & 0 & 13 & 1 & 1 & 1 & 16 & 21.05 \\
\hline Total & 4 & 42 & 5 & 9 & 16 & 76 & 100.00 \\
\hline
\end{tabular}

IAJ, Investment Analysts Journal; MedAR, Meditari Accountancy Research; SAJBM, South African Journal of Business Management; SAJEMS, South African Journal of Economic and Management Sciences; SAJAR, South African Journal of Accounting Research..

relevance of voluntary disclosure, and firm valuation. FR relates to preparers of financial information, e.g. accounting standards and risk-related disclosures. GV includes e.g. internal audit, directors, and shareholder oversight. IS relates to, for example, information systems, accounting software, and XBRL. MA covers, e.g. management accounting, control systems, and organisational learning and change. PS includes anything related to accounting in the public and voluntary sectors, inclusive of not-for-profit sectors and local governments. SE covers all aspects of social and environmental accounting, e.g. carbon accounting, and voluntary environmental and social disclosures. TX includes, for example, tax regimes and tax aggressiveness. Other captures, for example, accounting literature and theories, accounting history and accounting research.

None of the journals cover all EAA categories, with no research on the public sector in any of the journals. The top categories, ignoring Other, were in order from the top: Accounting Education, Social and Environmental, and Financial Analysis. The coverage of these accounting research areas, to a large extent, follow the focus of $\operatorname{MedAR}$, being the journal that published the most accounting research. A brief overview of the articles published follows.

Accounting and Information Systems (IS): Esterhuyse and Wingard (2016) assess the extent companies listed on the JSE comply with international best practice guidelines for investor relations practices based on analysis of corporate website contents.
Accounting Education (ED): There is a focus on enhancing the learning experience of accounting students and implementing methods of teaching to better prepare accounting students for their professional career. Sugahara et al. (2016) investigate the impact of a new interactive form of teaching on the learning motivation and performance on accounting undergraduate students in Japan. Stainbank and Gurr (2016) study whether accounting students in South Africa find social networking sites useful for their learning. Viviers, Fouché and Reitsma (2016) evaluate the usefulness of an educational game to develop soft skills. Van Oordt and Mulder (2016) describe the consequences of implementing basic e-learning tools in an undergraduate taxation curriculum. Kirstein and Kunz (2015) report on the development and implementation of two student-centred approaches, suggesting active student participation in large classes are possible and develops professional skills. Barac et al. (2016) describe factors that influence students' learning approaches in auditing. From a teaching perspective, Kirstein and Kunz (2016) examine whether learning style flexibility has been incorporated into accounting courses, Keevy (2016) examines educators' views on whether case studies can be used to transfer soft skills to students, and Samkin and Stainbank (2016) discuss the challenges faced by accounting teachers. Other topics include investigating the quality of accounting doctorates in South Africa (de Jager \& Frick 2016), gender and performance of accounting students (Callaghan \& Papageorgiou 2015). 
Auditing (AU): Soni et al. (2015) applies organisational justice theory in examining variations in the tendency for trainee auditors in South Africa to whistle blow on a leader's internal misconduct. Hay (2015) reviews literature to identify current issues in auditing research.

Financial Analysis (FA): Studies have investigated the relation between CSR reporting or activities on market competition, stock returns, and financial performance (Marcia et al. 2015; Ruiz-Palomino, Pozo-Rubio \& MartínezCañas 2015; Ryu et al. 2016), and the potential impact of the Marikana incident on stock prices of mining companies listed on the JSE (Hill \& Maroun 2015). Huang, Su and Wang (2015) examine market reactions to seasoned equity offerings. Da Silva (2016) assesses the effect of earnings announcement on credit default swaps markets. Lin, Lai and Tang (2016) examine how liquidity and price discovery are affected by the incremental transparency provided by the limit-order book in Taiwan.

Badenhorst (2016) investigates whether investors price the future growth of acquisitions and the subsequent materialisation accurately. Oberholster, Koornhof and Vorster (2015) examine whether the financial information contained in interim reports is understood by individual shareholders. Atkins and Maroun (2015) explore the initial reactions of South African institutional investors on integrated reporting.

Financial Reporting (FR): Vivian and Hutcheson (2015) use principles by Adam Smith to develop a framework for annual financial statements applicable to property-casualty insurers. Scott, Wingard and van Biljon (2016) discuss the challenges public entities encounter with the application of Generally Recognised Accounting Practice 101. Badenhorst (2015) compares actual and stated fair value measurement policies to investigate the use and potential consequences of exchange-traded funds' equity investments.

Governance (GV): Studies have investigated into the relation between diversity, gender or racial, and financial performance (Taljaard et al. 2015; Willows \& van der Linde 2016). Islam, Sathye and $\mathrm{Hu}$ (2015) develop a corporate governance index and applied it in examining the relationship between corporate governance and bank performance. Mey and de Klerk (2015) examine whether having a Chartered Accountants South Africa as Chief Executive Officers is associated with accruals quality.

Management Accounting (MA): Morris (2015) investigates the movement in human capital efficiency of the workers of South African listed companies over time. Alkaraan (2016) focuses on strategic management accounting and examines the strategic investment decision-making processes of a case company.

Social and Environmental (SE): The process of developing environmental and social disclosures, or assessment of such reports, is a common focus. Del Sordo et al. (2016) analyse the contents disclosed in the social reports of Italian state universities' and discusses their motivations and difficulties faced. Massa et al. (2015) discusses the mechanisms and consequences involved in developing a sustainability report for a small to medium enterprise. Leung and Gray (2016) explore the relevance of social responsibility and social and environmental reporting to controversial industries. Borghei, Leung and Guthrie (2016) explore voluntary greenhouse gas disclosures after the introduction of the National Greenhouse and Energy Reporting Act 2007 and before the introduction of the Australian ETS. Stent and Dowler (2015) assess the gap between current corporate reporting and integrated reporting principles. Other topics include investigating the role of moral philosophy and ethics in CSR activities and disclosure (Ackers 2015), whether Buddhism is informing the sustainability practices of corporations in Sri Lanka (Abeydeera, Tregidga \& Kearins 2016), the moderating effect of cultural dimensions on the relation between environmental and social disclosures and profitability (Khlif et al. 2015), and emergence of integrated private reporting (Atkins et al. 2015). Yoo and Nam (2015) proposed an accounting framework to provide information on both financial information of a focal firm and stakeholder relationships. Rao and Tilt (2016) examine the relationship between board diversity and CSR reporting. Maroun (2015a) discusses key limitations to meta-analyses that assess the correlation between corporate social environmental disclosures and financial measures.

Taxation (TX): Maroun (2015b) assesses section 24JB of the Income Tax Act No. 58 of 1962 and the International Financial Reporting Standards 9, suggesting potential for dysfunctional consequences following adoption of a fair value taxation regime for financial instruments. Junpath, Kharwa and Stainbank (2016) surveyed taxpayers regarding their attitudes towards tax amnesties and tax compliance.

Other: Researchers have investigated into accounting for the Bitcoin (Ram, Maroun \& Garnett 2016), frameworks used to examine fraud (Free 2015), power exerted by accountants on small enterprises (Stone 2015), earnings management (Liu 2016; Pududu \& de Villiers 2016), gender in accounting (Broadbent 2016; Galizzi \& Siboni 2016; Siboni et al. 2016; Zhao \& Lord 2016), analysis of performance or publications of academic journals (Murphy \& Maguire 2015; Ngulube \& Ngulube 2015), central banks with private shareholders (Rossouw 2016), accounting historiography (Parker 2015), theory of autopoiesis and its association with sustainability (Khan \& Gray 2016), the legitimacy of the International Financial Reporting Standards (Wingard, Bosman \& Amisi 2016) and review of the use of Hofstede's cultural dimensions in accounting research (Khlif 2016).

\section{Relevance to practice}

Table 6 shows the stated contributions of the 2015-2016 articles. Papers may have specified multiple contributions. If so, the papers are coded in multiple categories. 
A common contribution stated by studies is extending the current literature by improving research methodology, such as considering analysis of additional variables for a particular research topic or extended time periods or databases (Marcia et al. 2015; Taljaard et al. 2015; Ryu et al. 2016). Studies also express addressing knowledge gaps in current literature (Barac et al. 2016; Huang et al. 2015; Leung \& Gray 2016), and develop theories (Ram et al. 2016). Suggestions for future research are also common (Free 2015; Siboni et al. 2016).

A few studies are targeted at practitioners. Research that may be relevant to the accounting profession includes those that investigated into whistle-blowing in the audit profession (Soni et al. 2015), relationship between accountants and small businesses (Stone 2015), and suggested the need to develop education regarding non-financial performance and assurance (Ackers 2015). For investors, there have been suggestions for improvements in investment analysis methods (Liu 2016), and indication of factors to consider for in the appointment of a CEO (Mey \& de Klerk 2015).

Studies relevant to managers are those, for instance, related to identifying aspects or factors to consider to improve corporate disclosures (Atkins \& Maroun 2015), corporate policies (Khlif et al. 2015), and corporate governance (Willows \& van der Linde 2016).

For educators, studies have suggested the use of technology and social media as beneficial for student learning (Stainbank \& Gurr 2016, van Oordt \& Mulder 2016) and implementation of innovative and student-focused teaching styles (Kirstein \& Kunz 2015, Viviers et al. 2016).

Articles targeted at contributing to policy or standard development includes Zhao and Lord (2016) who calls for enforcement of employment laws to support equal opportunity rights for women accountants in China, Stent and Dowler (2015) who developed an integrated reporting checklist and systems thinking proposal which could be used

TABLE 6: Stated contribution by articles - 2015-2016

\begin{tabular}{lcc}
\hline Contribution & Total $(\boldsymbol{n})$ & $\mathbf{\%}$ \\
\hline Accounting literature & 51 & 50.00 \\
Educators & 8 & 7.84 \\
Managers & 16 & 15.69 \\
Policy & 13 & 12.75 \\
Practitioners & 8 & 7.84 \\
Other & 6 & 5.88 \\
\hline Total & $\mathbf{1 0 2}$ & $\mathbf{1 0 0 . 0 0}$ \\
\hline
\end{tabular}

in assessing the potential and the additional requirements integrated reporting will impose on corporate reporting, and Lin et al. (2016) assessed the impact of introducing the limitorder book change event which may be considered by similar markets to Taiwan.

Articles classified under other are those that did not specifically state their contribution or are difficult to group into the other categories; for instance, Wingard et al. (2016) question the legitimacy of the International Financial Reporting Standard, Broadbent (2016) argues for reform towards a broader diversity agenda in the accounting profession, and Murphy and Maguire (2015) evaluate the future potential of MedAR.

\section{Research methods}

Table 7 shows the research approach applied by the researchers; this only applies to articles classified as research papers or case studies.

The literature reviews and general reviews are classified under 'Not Applicable' (Maroun 2015a; Siboni et al. 2016). Mixed methods are generally characterised by a combination of questionnaires and focus groups or interviews (Stone 2015; Viviers et al. 2016). Qualitative methods involve action research (Kirstein \& Kunz 2015), case studies (Kirstein \& Kunz 2016), focus group discussions (Barac et al. 2016), and interviews (Atkins \& Maroun 2015). Quantitative methods include survey and questionnaires (Oberholster et al. 2015; Del Sordo et al. 2016), regression analysis (Ryu et al. 2016; Willows \& van der Linde 2016) or other descriptive statistics and graphical descriptions (de Jager \& Frick 2016; Pududu \& de Villiers 2016). Content analysis could be either employed qualitatively by interpreting the text (Abeydeera et al. 2016), or quantitatively by quantifying the text to data for statistical analysis (Borghei et al. 2016).

\section{Most prolific authors}

The most prolific authors and institutions cover all individuals who published in the five journals and are not limited to those that published accounting articles. For each paper, all individual authors and institutions were counted to have one publication even when papers may involve multiple authors and institutions.

Table 8 lists the authors who published more than three articles during 2015-2016 and shows the number of articles

TABLE 7: Research approaches.

\begin{tabular}{|c|c|c|c|c|c|c|c|}
\hline \multirow[t]{2}{*}{ Approaches } & \multicolumn{5}{|c|}{ Journals } & \multirow[t]{2}{*}{ Total $(n)$} & \multirow[t]{2}{*}{$\%$} \\
\hline & IAJ & MedAR & SAJBM & SAJEMS & SAJAR & & \\
\hline Qualitative & 0 & 9 & 0 & 1 & 2 & 12 & 15.79 \\
\hline Quantitative & 4 & 16 & 5 & 6 & 13 & 44 & 57.89 \\
\hline Pragmatic - mixed & 0 & 5 & 0 & 0 & 1 & 6 & 7.89 \\
\hline Not applicable & 0 & 12 & 0 & 2 & 0 & 14 & 18.42 \\
\hline Total & 4 & 42 & 5 & 9 & 16 & 76 & 100.00 \\
\hline
\end{tabular}

IAJ, Investment Analysts Journal; MedAR, Meditari Accountancy Research; SAJBM, South African Journal of Business Management; SAJEMS, South African Journal of Economic and Management Sciences; SAJAR, South African Journal of Accounting Research. 
in total and the number of these articles that were classified in each of the subject areas. The most prolific accounting author, by far, was Warren Maroun.

Table 9 lists universities with more than five papers published in the five journals during 2015-2016. The University of Pretoria and the University of the Witwatersrand feature prominently in terms of accounting articles. Most of the universities listed are South African, except the University of Bologna (Italy).

Table 10 lists the geographical regions the author(s) were associated with at the time of publication.

South Africa authors account for 159 of the 164 authors from Africa, the rest are spread through Nigeria, Tanzania, Tunisia and Zambia. From Asia, the greatest contributors are from South Korea (10/42), China (8/42), Taiwan (7/42) and the remainder by individuals in Hong Kong, India, Iran, Japan,

TABLE 8: Most prolific authors (number of articles 2015-2016).

\begin{tabular}{|c|c|c|c|c|c|c|}
\hline Author & Total & ACCT & ECON & FINA & MNGT & Other \\
\hline Warren Maroun & 8 & 8 & 0 & 0 & 0 & 0 \\
\hline Gary van Vuuren & 6 & 0 & 5 & 1 & 0 & 0 \\
\hline Melville Saayman & 6 & 0 & 2 & 0 & 0 & 4 \\
\hline Charl de Villiers & 4 & 4 & 0 & 0 & 0 & 0 \\
\hline Margie Sutherland & 4 & 0 & 0 & 0 & 4 & 0 \\
\hline Benedetta Siboni & 3 & 3 & 0 & 0 & 0 & 0 \\
\hline Christa Wingard & 3 & 3 & 0 & 0 & 0 & 0 \\
\hline David Bradfield & 3 & 0 & 0 & 3 & 0 & 0 \\
\hline Federica Farneti & 3 & 3 & 0 & 0 & 0 & 0 \\
\hline Marina Kirstein & 3 & 3 & 0 & 0 & 0 & 0 \\
\hline Mark Bussin & 3 & 0 & 0 & 0 & 3 & 0 \\
\hline Michael Ward & 3 & 1 & 0 & 2 & 0 & 0 \\
\hline Pierre Mostert & 3 & 0 & 0 & 0 & 0 & 3 \\
\hline Rolien Kunz & 3 & 3 & 0 & 0 & 0 & 0 \\
\hline Wessel M. Badenhorst & 3 & 3 & 0 & 0 & 0 & 0 \\
\hline
\end{tabular}

ACCT, Accountancy; ECON, Economics; FINA, Financial; MNGT, Management.
Malaysia, Pakistan and Saudi Arabia. From Australasia, 13/24 is based in Australia, while 11/24 is from New Zealand. For Europe, the highest contribution is from United Kingdom $(13 / 42)$, with the remainder from Austria, Belgium, Italy, Netherland, Poland, Portugal, Serbia, Spain, Sweden, Switzerland and Turkey. For North America, 6/10 is from Canada, 3/10 from the United States and 1/10 from Mexico. The one South American author was from Brazil.

IAJ and MedAR have the lowest percentages of published authors from Africa, reflecting a greater level of internationalisation than the other two internationalising journals, SAJBM and SAJEMS. SAJAR appears to be very parochial, mostly publishing articles by African authors. These latter journals declare themselves as South African in their titles and this may have a bearing on the efforts of $S A J B M$ and SAJEMS to internationalise, whereas $S A J A R$ may not be interested in the international research community at all.

\section{Conclusion}

This study identifies four South African journals that publish accounting research articles, journals that are also internationalising, as shown by their inclusion in Scopus. The four journals are IAJ, MedAR, SAJBM and SAJEMS. These journals are contrasted with the premier South African accounting journal, SAJAR. The study's analyses show that many of the highly cited articles have been published during or since 2015. This may be indicative of the international community starting to notice and cite work from these journals and if this trend continues, future citation statistics will benefit. Thus, these journals show signs of success in their efforts to internationalise. The citations of SAJAR lag behind those of the four internationalising journals, providing evidence that reliance on a largely South African support base, without tapping into the international accounting

TABLE 9: Top universities (number of articles during 2015-2016).

\begin{tabular}{|c|c|c|c|c|c|c|}
\hline University & Total & ACCT & ECON & FINA & MNGT & Other \\
\hline North-West University & 36 & 3 & 17 & 2 & 5 & 9 \\
\hline University of Pretoria & 36 & 17 & 4 & 4 & 8 & 3 \\
\hline University of the Witwatersrand & 27 & 15 & 5 & 4 & 3 & 0 \\
\hline University of Cape Town & 18 & 8 & 1 & 6 & 2 & 1 \\
\hline University of South Africa & 18 & 7 & 1 & 2 & 4 & 4 \\
\hline University of Stellenbosch & 18 & 6 & 6 & 5 & 0 & 1 \\
\hline University of Bologna & 8 & 8 & 0 & 0 & 0 & 0 \\
\hline University of Johannesburg & 7 & 1 & 2 & 0 & 3 & 1 \\
\hline Rhodes University & 6 & 3 & 0 & 3 & 0 & 0 \\
\hline
\end{tabular}

ACCT, Accountancy; ECON, Economics; FINA, Financial; MNGT, Management.

TABLE 10: Geographical regions of published authors.

\begin{tabular}{|c|c|c|c|c|c|c|c|}
\hline \multirow[t]{2}{*}{ Regions } & \multicolumn{5}{|c|}{ Journals } & \multirow[t]{2}{*}{ Total $(n)$} & \multirow[t]{2}{*}{$\%$} \\
\hline & IAJ & MedAR & SAJBM & SAJEMS & SAJAR & & \\
\hline Africa & 11 & 23 & 36 & 57 & 37 & 164 & 57.95 \\
\hline Asia & 16 & 2 & 15 & 6 & 3 & 42 & 14.84 \\
\hline Australasia & 1 & 17 & 3 & 1 & 2 & 24 & 8.48 \\
\hline Europe & 6 & 15 & 11 & 10 & 0 & 42 & 14.84 \\
\hline North America & 4 & 1 & 3 & 2 & 0 & 10 & 3.53 \\
\hline
\end{tabular}


research community, leads to the maintenance of a stagnant position, whereas internationalising journals are moving ahead. The fact that $S A J A R^{\prime}$ s board appears to be dominated by non-academics and non-researchers (e.g. the editor in chief) can be taken as a signal that the journal has no interest in integrating with the international research community.

Each journal publishes articles that cover different subject area(s), with $I A J$ publishing mostly finance, MedAR and $S A J A R$ publishing mostly accounting, SAJBM mostly management, and SAJEMS mostly economics and management. When considering accounting research only, accounting education and social and environmental accounting are popular focus areas. By contrast, taxation, the public sector, and management accounting are not well represented among published articles during 2015-2016 in these five journals. Accounting articles claim to contribute in different ways, with about half claiming to contribute to the accounting literature, and much smaller percentages claiming to contribute to management, policy-making, and practice. The most prolific authors and most prominent universities make for interesting reading and, to some extent, follow the most popular subject areas. For example, Warren Maroun, who does social and environmental research, is the most prolific accounting author, and his university, the University of the Witwatersrand, features strongly. Large proportions of authors of 2015-2016 articles are from outside of Africa, which can again be taken as evidence of success in the internationalisation efforts of the four internationalising journals.

Overall, the evidence points towards IAJ and MedAR being more successful in their internationalisation efforts and reaping the benefits of more articles by non-African authors and increased citations for published papers. Having 'South African' in the name of a journal appears to work against efforts to internationalise, or otherwise it may be reflective of an underlying editorial philosophy to remain true to the initial target audience of the journal and not to aggressively pursue a strategy to internationalise. Journal editors and authors who would like their research to make an impact and be cited will be interested in these findings.

\section{Acknowledgements Competing interests}

The authors declare that they have no financial or personal relationships that may have inappropriately influenced them in writing this article.

\section{Authors' contributions}

Both authors contributed equally to the write-up of this article.

\section{References}

Abdo, A. \& Fisher, G., 2007, 'The impact of reported corporate governance disclosure on the financial performance of companies listed on the JSE', Investment Analysts Journal 36(66), 43-56.
Abeydeera, S., Tregidga, H. \& Kearins, K., 2016, 'Sustainability reporting - More global than local?', Meditari Accountancy Research 24(4), 478-504. https://doi. org/10.1108/MEDAR-09-2015-0063

Abor, J. \& Biekpe, N., 2006, 'An empirical test of the agency problems and capital structure of South African quoted SMEs', South African Journal of Accounting Research 20(1), 51-65. https://doi.org/10.1080/10291954.2006.11435121

Acaravci, S.K., Ozturk, I. \& Acaravci, A., 2009, 'Financial development and economic growth: Literature survey and empirical evidence from sub-Saharan African countries', South African Journal of Economic and Management Sciences 12(1), 11-27. https://doi.org/10.4102/sajems.v12i1.258

Ackers, B., 2009, 'Corporate social responsibility assurance: How do South African publicly listed companies compare?', Meditari Accountancy Research 17(2), 1-17. https://doi.org/10.1108/10222529200900009

Ackers, B., 2015, 'Ethical considerations of corporate social responsibility - A South African perspective', South African Journal of Business Management 46(1), 11-21.

Al-Jabri, I.M., 2015, 'The intention to use mobile banking: Further evidence from Saudi Arabia', South African Journal of Business Management 46(1), 23-34.

Alkaraan, F., 2016, 'Strategic investment decision-making - Scanning and screening investment opportunities: The expansion of Guinness in West Africa', Meditari Accountancy Research 24(4), 505-526. https://doi.org/10.1108/MEDAR-012016-0007

Atkins, J. \& Maroun, W., 2015, 'Integrated reporting in South Africa in 2012: Perspectives from South African institutional investors', Meditari Accountancy Research 23(2), 197-221. https://doi.org/10.1108/MEDAR-07-2014-0047

Atkins, J.F., Solomon, A., Norton, S. \& Joseph, N.L., 2015, 'The emergence of integrated private reporting', Meditari Accountancy Research 23(1), 28-61.

Auret, C.J. \& Sinclaire, R.A., 2006, 'Book-to-market ratio and returns on the JSE', Investment Analysts Journal 35(63), 31-38.

Baard, R.S., Steenkamp, L.P., Frick, B.L. \& Kidd, M., 2010, 'Factors influencing success in first-year Accounting at a South African university: The profile of a successful first-year Accounting student', South African Journal of Accounting Research 24(1), 129-147. https://doi.org/10.1080/10291954.2010.11435150

Badenhorst, W.M., 2015, 'Fair value measurements of exchange-traded funds', Meditari Accountancy Research 23(3), 331-347. https://doi.org/10.1108/MEDAR06-2014-0045

Badenhorst, W.M., 2016, 'Acquisitions and the value versus growth phenomenon', Meditari Accountancy Research 24(1), 56-72. https://doi.org/10.1108/MEDAR01-2015-0005

Badenhorst, W.M., Brümmer, L.M. \& de Wet, J.H.v.H., 2016, 'The value-relevance of listed associates: A cross-country investigation', South African Journal of Accounting Research 30(1), 61-78. https://doi.org/10.1080/10291954.2015.1054 118

Barac, K., 2009, 'South African training officers' perceptions of the knowledge and skills requirements of entry-level trainee accountants', Meditari Accountancy Research 17(2), 19-46. https://doi.org/10.1108/10222529200900010

Barac, K., Kirstein, M., Kunz, R. \& Beukes, B., 2016, 'Factors influencing students' learning approaches in auditing', Meditari Accountancy Research 24(3), 390-413. https://doi.org/10.1108/MEDAR-06-2013-0018

Beaumont, S.M. \& Begemann, E., 1997, 'Measuring associations between working capital and return on investment', South African Journal of Business Management 28(1), 1-5.

Benson, K., Clarkson, P.M., Smith, T. \& Tutticci, I., 2015, 'A review of accounting research in the Asia Pacific region', Australian Journal of Management 40(1), 3688. https://doi.org/10.1177/0312896214565121

Boonzaier, B., Ficker, B. \& Rust, B., 2001, 'A review of research on the Job Characteristics Model and the attendant job diagnostic survey', South African Journal of Business Management 32(1), 11.

Booysen, L., 2007, 'Societal power shifts and changing social identities in South Africa: Workplace implications', South African Journal of Economic and Management Sciences 10(1), 1-20. https://doi.org/10.4102/sajems.v10i1.533

Borghei, Z., Leung, P. \& Guthrie, J., 2016, 'The nature of voluntary greenhouse gas disclosure - An explanation of the changing rationale: Australian evidence' Meditari Accountancy Research 24(1), 111-133. https://doi.org/10.1108/ MEDAR-02-2015-0008

Boshoff, C. \& Gray, B., 2004, 'The relationships between service quality, customer satisfaction and buying intentions in the private hospital industry', South African Journal of Business Management 35(4), 27-37.

Botha, M., van Vuuren, J.J. \& Kunene, T., 2015, 'An integrated entrepreneurial performance model focusing on the importance and proficiency of competencies for start-up and established SMEs', South African Journal of Business Management 46(3), 55-65.

Bowie, D.C. \& Bradfield, D.J., 1997, 'Some evidence on the stability of beta coefficients on the JSE', South African Journal of Accounting Research 11(2), 1-20. https://doi. org/10.1080/10291954.1997.11435071

Broadbent, J., 2016, 'A gender agenda', Meditari Accountancy Research 24(2), 169181. https://doi.org/10.1108/MEDAR-07-2015-0046

Buitendach, J.H. \& De Witte, H., 2005, 'Job insecurity, extrinsic and intrinsic job satisfaction and affective organisational commitment of maintenance workers in a parastatal', South African Journal of Business Management 36(2), 27.

Burra, P., de Jongh, P.J., Raubenheimer, H., van Vuuren, G. \& Wiid, H., 2015 Implementing the countercyclical capital buffer in South Africa: Practical considerations', South African Journal of Economic and Management Sciences 18(1), 105-127. https://doi.org/10.4102/sajems.v18i1.956 
Bussin, M., 2015, 'CEO pay-performance sensitivity in the South African context', South African Journal of Economic and Management Sciences 18(2), 232-244. https://doi.org/10.4102/sajems.v18i2.838

Callaghan, C. \& Papageorgiou, E., 2015, 'Gender differences in locus of control and student performance in the South African context of accounting studies', Meditari Accountancy Research 23(3), 348-368. https://doi.org/10.1108/MEDAR-022014-0018

Chang, B.Y., Magobe, M.J. \& Kim, Y.B., 2015, 'E-commerce applications in the tourism industry: A Tanzania case study', South African Journal of Business Management $46(4), 53-63$.

Coetsee, D., 2011, 'A comment on research frameworks applied in accounting research', South African Journal of Accounting Research 25(1), 81-102. https:// doi.org/10.1080/10291954.2011.11435154

Coetzee, M., 2015, 'The perceived treatment of employees from designated groups in the workplace', South African Journal of Economic and Management Sciences 18(1), 56-69. https://doi.org/10.17159/2222-3436/2015/v18n1a5

Correia, C. \& Cramer, P., 2008, 'An analysis of cost of capital, capital structure and capital budgeting practices: A survey of South African listed companies', Meditari Accountancy Research 16(2), 31-52. https://doi.org/10.1108/1022 2529200800011

Da Silva, P.P., 2016, 'Common-wide information flow in CDS markets: The case of earnings surprises of industry leaders', Investment Analysts Journal 45(2), 63-80. https://doi.org/10.1080/10293523.2015.1125062

De Jager, P. \& Frick, B.L., 2016, 'Accounting doctorates produced in South Africa 20082014', Meditari Accountancy Research 24(3), 438-457. https://doi.org/10.1108/ MEDAR-06-2015-0033

De Klerk, M. \& de Villiers, C., 2012, 'The value relevance of corporate responsibility reporting: South African evidence', Meditari Accountancy Research 20(1), 21-38. https://doi.org/10.1108/10222521211234200

Del Sordo, C., Farneti, F., Guthrie, J., Pazzi, S. \& Siboni, B., 2016, 'Social reports in Italian universities: Disclosures and preparers' perspective', Meditari Accountancy Research 24(1), 91-110. https://doi.org/10.1108/MEDAR-09-2014-0054

de Villiers, C.J. \& Barnard, P., 2000, 'Environmental reporting in South Africa from 1994 to 1999: A research note', Meditari Accountancy Research 8(1), 15-23. https://doi.org/10.1108/10222529200000002

de Villiers, R., 2010, 'The incorporation of soft skills into accounting curricula: Preparing accounting graduates for their unpredictable futures', Meditar Accountancy Research 18(2), 1-22. https://doi.org/10.1108/10222529201000007

de Wet, J.H., 2005, 'EVA versus traditional accounting measures of performance as drivers of shareholder value - A comparative analysis', Meditari Accountancy Research 13(2), 1-16. https://doi.org/10.1108/10222529200500009

de Wet, J.H.V.H. \& du Toit, E., 2007, 'Return on equity: A popular, but flawed measure of corporate financial performance', South African Journal of Business Management 38(1), 59-69.

Dhai, R., 2015, 'A comparison of the performance of the FTSE South Africa Islamic Index to the conventional market (JSE) in South Africa', South African Journal of Accounting Research 29(2), 101-114. https://doi.org/10.1080/10291954.2015.10 06481

Döckel, J.A. \& Ligthelm, A.A., 2005, 'Factors responsible for the growth of smal business', South African Journal of Economic and Management Sciences 8(1), 9 .

du Plessis, Y. \& Barkhuizen, N., 2012, 'Psychological capital, a requisite for organisational performance in South Africa', South African Journal of Economic and Management Sciences 15(1), 16-30. https://doi.org/10.4102/sajems. v15i1.122

Eloff, A.-M. \& de Villiers, C., 2015, 'The value-relevance of goodwill reported under IFRS 3 versus IAS 22', South African Journal of Accounting Research 29(2), 162 176. https://doi.org/10.1080/10291954.2015.1006485

Engelbrecht, A.S., Van Aswegen, A.S. \& Theron, C.C., 2005, 'The effect of ethical values on transformational leadership and ethical climate in organisations', South African Journal of Business Management 36(2), 19.

Eom, C., Park, J.W., Kim, Y.H. \& Kaizoji, T., 2015, 'Effects of the market factor on portfolio diversification: The case of market crashes', Investment Analysts Journal 44(1), 71-83.

Esterhuyse, L. \& Wingard, C., 2016, 'An exploration of the online investor relations (IR) practices of companies listed on the Johannesburg Stock Exchange (JSE)', South African Journal of Economic and Management Sciences 19(2), 215-231. https:// doi.org/10.4102/sajems.v19i2.1261

Fang, Y. \& Wang, H., 2015, 'Fund manager characteristics and performance', Investment Analysts Journal 44(1), 102-116.

Firer, S. \& Stainbank, L., 2003, 'Testing the relationship between intellectual capital and a company's performance: Evidence from South Africa', Meditari Accountancy Research 11(1), 25-44. https://doi.org/10.1108/10222529200300003

Firer, S. \& Williams, S.M., 2005, 'Firm ownership structure and intellectual capital disclosures', South African Journal of Accounting Research 19(1), 1-18. https:// doi.org/10.1080/10291954.2005.11435116

Fourie, D. \& Poggenpoel, W., 2017, 'Public sector inefficiencies: Are we addressing the root causes?', South African Journal of Accounting Research 31(3), 169-180. https://doi.org/10.1080/10291954.2016.1160197

Fraser, E. \& Page, M., 2000, 'Value and momentum strategies: Evidence from the Johannesburg Stock Exchange', Investment Analysts Journal 29(51), 25-35.

Free, C., 2015, 'Looking through the fraud triangle: A review and call for new directions', Meditari Accountancy Research 23(2), 175-196. https://doi. org/10.1108/MEDAR-02-2015-0009
Galizzi, G. \& Siboni, B., 2016, 'Positive action plans in Italian universities: Does gender really matter?', Meditari Accountancy Research 24(2), 246-268. https://doi. org/10.1108/MEDAR-09-2015-0062

Hall, J. \& Millard, S., 2010, 'Capital budgeting practices used by selected listed South African firms', South African Journal of Economic and Management Sciences 13(1), 85-97. https://doi.org/10.4102/sajems.v13i1.200

Han, Q., Guo, B., Ryu, D. \& Webb, R.I., 2012, 'Asymmetric and negative returnvolatility relationship: The case of the VKOSPI', Investment Analysts Journal 41(76), 69-78.

Harris, G. \& Vermaak, C., 2015, 'Economic inequality as a source of interpersonal violence: Evidence from sub-Saharan Africa and South Africa', South African Journal of Economic and Management Sciences 18(1), 45-57. https://doi. org/10.4102/sajems.v18i1.782

Hay, D., 2015, 'The frontiers of auditing research', Meditari Accountancy Research 23(2), 158-174. https://doi.org/10.1108/MEDAR-12-2014-0062

Hesketh, J.H., 2011, 'Accounting academics' multiple challenges: Issues-driven learning offers a way forward', South African Journal of Accounting Research 25(1), 1-34. https://doi.org/10.1080/10291954.2011.11435151

Hill, N. \& Maroun, W., 2015, Assessing the potential impact of the Marikana incident on South African mining companies: An event method study', South African Journal of Economic and Management Sciences 18(4), 586-607. https://doi. org/10.4102/sajems.v18i4.1345

Huang, H.-C., Su, Y.-C. and Wang, H.-Y., 2015, 'Convergence to market efficiency: The case of seasoned equity offering stocks', Investment Analysts Journal 44(1), 5770.

Islam, J., Sathye, M. \& Hu, H., 2015, 'Examining the relationship between corporate governance and bank performance in Bangladesh', South African Journal of Business Management 46(4), 43-51.

Jansen, J. \& de Villiers, C., 2016, 'Determinants of student performance in an accounting degree programme', South African Journal of Accounting Research 30(1), 1-28. https://doi.org/10.1080/10291954.2015.1019223

Jefferis, K.R. \& Okeahalam, C.C., 1999, 'International stock market linkages in Southern Africa', South African Journal of Accounting Research 13(2), 27-51. https://doi.or $\mathrm{g} / 10.1080 / 10291954.1999 .11435087$

Jonck, P. \& Swanepoel, E., 2015, 'Exploring the theoretical link between cultural and emotional intelligence: A system analysis for human resource management', South African Journal of Business Management 46(4), 77-83.

Junpath, S.V., Kharwa, M.S.E. \& Stainbank, L.J., 2016, 'Taxpayers' attitudes towards tax amnesties and compliance in South Africa: An exploratory study', South African Journal of Accounting Research 30(2), 97-119. https://doi.org/10.1080/1029195 4.2015.1070565

Kalitanyi, V. \& Visser, K., 2010, 'African immigrants in South Africa: Job takers or job creators?', South African Journal of Economic and Management Sciences 13(4), 376-390. https://doi.org/10.4102/sajems.v13i4.91

Kandiero, T. \& Chitiga, M., 2006, 'Trade openness and foreign direct investment in Africa', South African Journal of Economic and Management Sciences 9(3), 16.

Katzke, N. \& Garbers, C., 2016, 'Do long memory and asymmetries matter when assessing downside return risk?', Investment Analysts Journal 45(3), 123-148. https://doi.org/10.1080/10293523.2015.1126916

Keevy, M., 2016, 'Using case studies to transfer soft skills (also known as pervasive skills): Empirical evidence', Meditari Accountancy Research 24(3), 458-474. https://doi.org/10.1108/MEDAR-04-2015-0021

Khan, T. \& Gray, R., 2016, 'Accounting, identity, autopoiesis + sustainability: A comment, development and expansion on Lawrence, Botes, Collins and Roper (2013)', Meditari Accountancy Research 24(1), 36-55. https://doi.org/10.1108/ MEDAR-06-2015-0032

Khlif, H., 2016, 'Hofstede's cultural dimensions in accounting research: A review', Meditari Accountancy Research 24(4), 545-573. https://doi.org/10.1108/ MEDAR-02-2016-0041

Khlif, H., Hussainey, K. \& Achek, I., 2015, 'The effect of national culture on the association between profitability and corporate social and environmental disclosure: A meta-analysis', Meditari Accountancy Research 23(3), 296-321. https://doi.org/10.1108/MEDAR-12-2014-0064

Kim, J.S. \& Ryu, D., 2015, 'Effect of the subprime mortgage crisis on a leading emerging market', Investment Analysts Journal 44(1), 20-42.

Kinnear, L. \& Sutherland, M., 2000, 'Determinants of organisational commitment amongst knowledge workers', South African Journal of Business Management 31(3), 106-112.

Kirstein, M. \& Kunz, R., 2015, 'Student-centred approach to teaching large classes: Friend or foe?', Meditari Accountancy Research 23(2), 222-246. https://doi. org/10.1108/MEDAR-06-2013-0025

Kirstein, M. \& Kunz, R., 2016, 'A whole brain ${ }^{\circledR}$ learning approach to an undergraduate auditing initiative - An exploratory study', Meditari Accountancy Research 24(4), 527-544. https://doi.org/10.1108/MEDAR-02-2014-0029

Kruger, L. \& Mostert, P., 2015, 'The influence of cell phone users' relationship intentions on expectations and perceptions of service recovery', South African Journal of Business Management 46(1), 57-69.

Kruger, M., Saayman, M. \& Slabbert, E., 2015, 'Managing visitors' dining and retail experiences in South African national parks', South African Journal of Business Management 46(1), 43-54.

Lee, C. \& Ryu, D., 2014, 'The volatility index and style rotation: Evidence from the Korean stock market and VKOSPI', Investment Analysts Journal 43(79), 29-39. 
Lee, C.S., Chao, C.W. \& Chen, H.I., 2015, 'The relationship between HRM practices and the service performance of student interns: Industry perspective', South African Journal of Business Management 46(3), 1-10.

Lee, H.S. \& Yao, J., 2015, 'Evaluating and predicting the failure probabilities of hedge funds', Investment Analysts Journal 44(2), 134-150. https://doi.org/10.1080/102 93523.2014.994456

Leung, T.C.H. \& Gray, R., 2016, 'Social responsibility disclosure in the international gambling industry: A research note', Meditari Accountancy Research 24(1), 73-90. https://doi.org/10.1108/MEDAR-01-2015-0001

Li, F., 2016, 'Endogeneity in CEO power: A survey and experiment', Investment Analysts Journal 45(3), 149-162. https://doi.org/10.1080/10293523.2016.11519 85

Ligthelm, A., 2008, 'The impact of shopping mall development on small township retailers', South African Journal of Economic and Management Sciences 11(1) 37-53. https://doi.org/10.4102/sajems.v11i1.376

Lin, C.-F., Lai, Y.-W. \& Tang, M.-L., 2016, 'Is the incremental transparency necessary?', Investment Analysts Journal 45(2), 95-109. https://doi.org/10.1080/10293523.20 15.1126782

Liu, Z.J., 2016, 'Effect of earnings management on economic value added: A crosscountry study', South African Journal of Business Management 47(1), 29-36.

Loliwe, T., 2016, 'Voluntary employee reporting by the wholesale and retail companies listed on the Johannesburg Stock Exchange', South African Journal of Accounting Research 30(2), 139-171. https://doi.org/10.1080/10291954.2015.1099216

Mansfield, G.M. \& Fourie, L.C.H., 2004, 'Strategy and business models-strange bedfellows? A case for convergence and its evolution into strategic architecture', South African Journal of Business Management 35(1), 35-44.

Marcia, A., Callaghan, C. \& Maroun, W., 2015, 'Value relevance and corporate responsibility reporting in the South African context: An alternate view post KingIII', South African Journal of Economic and Management Sciences 18(4), 500-518. https://doi.org/10.4102/sajems.v18i4.1192

Maroun, W., 2015a, 'Culture, profitability, non-financial reporting and a meta-analysis: Comments and observations', Meditari Accountancy Research 23(3), 322-330.

Maroun, W., 2015b, 'Peculiarities of the fair value taxation regime for financial instruments', South African Journal of Accounting Research 29(2), 151-161.

Marx, B. \& van Dyk, V., 2011, 'Sustainability reporting and assurance: An analysis of assurance practices in South Africa', Meditari Accountancy Research 19(1/2), 39 55. https://doi.org/10.1108/10222521111178628

Massa, L., Farneti, F. \& Scappini, B., 2015, 'Developing a sustainability report in a small to medium enterprise: Process and consequences', Meditari Accountancy Research 23(1), 62-91. https://doi.org/10.1108/MEDAR-02-2014-0030

Mey, E. \& de Klerk, M., 2015, 'Association between having a CA(SA) as CEO and accruals quality', Meditari Accountancy Research 23(3), 276-295. https://doi. org/10.1108/MEDAR-09-2014-0056

Miller, C. \& Ward, M., 2015, 'The market impact on shares entering or leaving JSE indices', Investment Analysts Journal 44(1), 84-101.

Mlambo, C. \& Biekpe, N., 2007, 'The efficient market hypothesis: Evidence from ten African stock markets', Investment Analysts Journal 36(66), 5-17.

Moodley, T., Ward, M. \& Muller, C., 2017, 'The relationship between the management of payables and the return to investors', South African Journal of Accounting Research 31(1), 35-43. https://doi.org/10.1080/10291954.2015.1105555

Morris, C., 2015, 'Developments in the value-added efficiency of South African workers - An exploratory study', South African Journal of Business Management $46(4), 35-42$

Muller, C. \& Ward, M., 2013, 'Style-based effects on the Johannesburg stock exchange: A graphical time-series approach', Investment Analysts Journal 42(77), 1-16.

Murphy, L. \& Maguire, W., 2015, 'Twenty-one years of publishing Meditari Accountancy Research: A coming of age', Meditari Accountancy Research 23(1), 2-27. https://doi.org/10.1108/MEDAR-02-2014-0019

Myburgh, J.E., 2005, 'An empirical analysis of career choice factors that influence firstyear accounting students at the University of Pretoria: A cross-racial study', Meditari Accountancy Research 13(2), 35-48. https://doi.org/10.1108/102 22529200500011

Myers, L.P., 2016, 'Knowledge structures and their relevance for teaching and learning in introductory financial accounting', South African Journal of Accounting Research 30(1), 79-95. https://doi.org/10.1080/10291954.2015.1099215

Naidoo, S. \& Sutherland, M., 2016, 'A management dilemma: Positioning employees for internal competition versus internal collaboration. Is coopetition possible?', South African Journal of Business Management 47(1), 75-87.

Ngulube, P. \& Ngulube, B., 2015, 'Mixed methods research in the South African Journal of Economic and Management Sciences: An investigation of trends in the literature', South African Journal of Economic and Management Sciences 18(1) 1-13. https://doi.org/10.4102/sajems.v18i1.633

Oberholster, J.G., Koornhof, C. \& Vorster, Q., 2015, 'Individual shareholders' understanding of the content of interim reports of South African listed retail companies', South African Journal of Economic and Management Sciences 18(2) 177-189. https://doi.org/10.1108/10222529200400009

Oberholzer, M. \& van der Westhuizen, G., 2004, 'An empirical study on measuring efficiency and profitability of bank regions', Meditari Accountancy Research 12(1), 165-178.

Özer, G., Ergun, E. \& Yılmaz, O., 2015, 'Effects of intellectual capital on qualitative and quantitative performance: Evidence from Turkey', South African Journal of Economic and Management Sciences 18(2), 143-154. https://doi.org/10.4102/ sajems.v18i2.669
Packendorff, J. \& Lindgren, M., 2014, 'Projectification and its consequences: Narrow and broad conceptualisations', South African Journal of Economic and Management Sciences 17(1), 7-21. https://doi.org/10.4102/sajems.v17i1.807

Page, M.J. \& Way, C.V., 1992, 'Stock market over-reaction: The South African evidence', Investment Analysts Journal 21(36), 35-49.

Pamburai, H.H., Chamisa, E., Abdulla, C. \& Smith, C., 2015, 'An analysis of corporate governance and company performance: A South African perspective', South African Journal of Accounting Research 29(2), 115-131. https://doi.org/10.1080/ 10291954.2015.1006482

Parker, L., 2015, 'Accounting historiography: Looking back to the future', Meditari Accountancy Research 23(2), 142-157. https://doi.org/10.1108/MEDAR-032015-0018

Pretorius, M., 2008, 'Critical variables of business failure: A review and classification framework', South African Journal of Economic and Management Sciences 11(4) 408-430.

Pretorius, M. \& Shaw, G., 2004, 'Business plans in bank decision-making when financing new ventures in South Africa', South African Journal of Economic and Management Sciences 7(2), 221-241. https://doi.org/10.4102/sajems. v7i2.1377

Pududu, M.L. \& de Villiers, C., 2016, 'Earnings management through loss avoidance: Does South Africa have a good story to tell?', South African Journal of Economic and Management Sciences 19(1), 18-34. https://doi.org/10.4102/sajems. v19i1.1124

Raemaekers, K., Maroun, W. \& Padia, N., 2016, 'Risk disclosures by South African listed companies post-King III', South African Journal of Accounting Research 30(1), 4160. https://doi.org/10.1080/10291954.2015.1021583

Ram, A., Maroun, W. \& Garnett, R., 2016, 'Accounting for the Bitcoin: Accountability, neoliberalism and a correspondence analysis', Meditari Accountancy Research 24(1), 2-35. https://doi.org/10.1108/MEDAR-07-2015-0035

Rao, K. \& Tilt, C., 2016, 'Board diversity and CSR reporting: An Australian study', Meditari Accountancy Research 24(2), 182-210. https://doi.org/10.1108/ MEDAR-08-2015-0052

Rosenstreich, D. \& Wooliscroft, B., 2009, 'Measuring the impact of accounting journals using Google Scholar and the g-index', The British Accounting Review 41(4), 227239. https://doi.org/10.1016/j.bar.2009.10.002

Rossouw, J., 2016, 'Private shareholding: An analysis of an eclectic group of central banks', South African Journal of Economic and Management Sciences 19(1), 150159. https://doi.org/10.4102/sajems.v19i1.1329

Rothmann, S. \& Joubert, J.H.M., 2007, 'Job demands, job resources, burnout and work engagement of managers at a platinum mine in the North West Province', South African Journal of Business Management 38(3), 49-61.

Rothmann, S., Steyn, L.J. \& Mostert, K., 2005, 'Job stress, sense of coherence and work wellness in an electricity supply organisation', South African Journal of Business Management 36(1), 55

Ruiz-Palomino, P., Pozo-Rubio, R.D. \& Martínez-Cañas, R., 2015, 'Risk and return characteristics of environmentally and socially responsible firms in Spain during a financial downturn: 2008-2011', South African Journal of Business Management 46(1), 65-76.

Ryu, D., 2012, 'The profitability of day trading: An empirical study using high-quality data', Investment Analysts Journal 41(75), 43-54.

Ryu, D., Ryu, D. \& Hwang, J.H., 2016, 'Corporate social responsibility, market competition, and shareholder wealth', Investment Analysts Journal 45(1), 16-30. https://doi.org/10.1080/10293523.2015.1125059

Saayman, M. \& Dieske, T., 2015, 'Segmentation by motivation of tourists to the Kgalagadi Transfrontier Park', South African Journal of Business Management 46(1), 77-88.

Samkin, G. \& Schneider, A., 2014a, 'The accounting academic', Meditari Accountancy Research 22(1), 2-19.

Samkin, G. \& Schneider, A., 2014b, 'Using university websites to profile accounting academics and their research output: A three country study', Meditari Accountancy Research 22(1), 77-106

Samkin, G. \& Stainbank, L., 2016, 'Teaching and learning: Current and future challenges facing accounting academics, academics, and the development of an agenda for future research', Meditari Accountancy Research 24(3), 294-317. https://doi.org/10.1108/MEDAR-05-2016-0062

Schaltegger, S., Gibassier, D. \& Zvezdov, D., 2013, 'Is environmental management accounting a discipline? A bibliometric literature review', Meditari Accountancy Research 21(1), 4-31. https://doi.org/10.1108/MEDAR-12-2012-0039

Schoeman, N.J., Robinson, C.Z. \& de Wet, T.J., 2000, 'Foreign direct investment flows and fiscal discipline in South Africa', South African Journal of Economic and Management Sciences 3(2), 235-244.

Scholtz, H. \& Smit, A.-R., 2015, 'Factors influencing corporate governance disclosure of companies listed on the Alternative Exchange (AltX) in South Africa', South African Journal of Accounting Research 29(1), 29-50. https://doi.org/10.1080/10291954. 2015.999471

Scott, D., Wingard, C. \& van Biljon, M., 2016, 'Challenges with the financial reporting of biological assets by public entities in South Africa', South African Journal of Economic and Management Sciences 19(1), 139-149. https://doi.org/10.4102/ sajems.v19i1.1339

Sethibe, T.G. \& Steyn, R., 2015, 'The relationship between leadership styles, innovation and organisational performance: A systematic review', South African Journal of Economic and Management Sciences 18(3), 325-337. https://doi.org/10.17159/ 2222-3436/2015/v18n3a3 
Siboni, B., Sangiorgi, D., Farneti, F. \& de Villiers, C., 2016, 'Gender (in) accounting: Insights, gaps and an agenda for future research', Meditari Accountancy Research 24(2), 158-168. https://doi.org/10.1108/MEDAR-04-2016-0054

Solomon, M. \& de Wet, W.A. 2004, 'The effect of a budget deficit on inflation: The case of Tanzania', South African Journal of Economic and Management Sciences 7(1), 100-116. https://doi.org/10.4102/sajems.v7i1.1431

Soni, F., Maroun, W. \& Padia, N., 2015, 'Perceptions of justice as a catalyst for whistleblowing by trainee auditors in South Africa', Meditari Accountancy Research 23(1), 118-140. https://doi.org/10.1108/MEDAR-01-2014-0004

Stainbank, L. \& Gurr, K.-L., 2016, 'The use of social media platforms in a first yea accounting course: An exploratory study', Meditari Accountancy Research 24(3), 318-340. https://doi.org/10.1108/MEDAR-08-2015-0051

Stainbank, L.J., 2010, 'Students' perceptions of the usefulness of an accounting project in acquiring accounting knowledge and professional skills', South African Journal of Accounting Research 24(1), 79-100. https://doi.org/10.1080/1029195 4.2010.11435148

Steenkamp, L.P., Baard, R.S. \& Frick, B.L., 2009, 'Factors influencing success in firstyear accounting at a South African university: A comparison between lecturers' assumptions and students' perceptions', South African Journal of Accounting Research 23(1), 113-140. https://doi.org/10.1080/10291954.2009.11435142

Stent, W. \& Dowler, T., 2015, 'Early assessments of the gap between integrated reporting and current corporate reporting', Meditari Accountancy Research 23(1), 92-117. https://doi.org/10.1108/MEDAR-02-2014-0026

Stone, G., 2015, 'Power, dependence and frustration: A study of power in Australian accountants' advisory relationship with small business', Meditari Accountancy Research 23(3), 250-275. https://doi.org/10.1108/MEDAR-05-2014-0042

Strugnell, D., Gilbert, E. \& Kruger, R., 2011, 'Beta, size and value effects on the JSE, 1994-2007', Investment Analysts Journal 40(74), 1-17.

Su, K., Wan, R. \& Feng, T., 2015, 'Government control structure and allocation of credit: Evidence from government-owned companies in China', Investment Analysts Journal 44(2), 151-170. https://doi.org/10.1080/10293523.2015.1020045

Sugahara, S., Sugao, H., Dellaportas, S. \& Masaoka, T., 2016, 'The effect of bodymovement teaching, learning motivation and performance', Meditari Accountancy Research 24(3), 414-437. https://doi.org/10.1108/MEDAR-02-2015-0006

Sutherland, M., Naidu, G., Seabela, S., Crosson, S. \& Nyembe, E., 2015, 'The components of career capital and how they are acquired by knowledge workers across different industries', South African Journal of Business Management 46(4), $1-10$.

Sutherland, M.M., Torricelli, D.G. \& Karg, R.F., 2002, ‘Employer-of-choice branding for knowledge workers', South African Journal of Business Management 33(4), 13.

Taljaard, C.C.H., Ward, M.J.D. \& Muller, C.J., 2015, 'Board diversity and financial performance: A graphical time-series approach', South African Journal of Economic and Management Sciences 18(3), 425-448. https://doi.org/10.4102/ sajems.v18i3.926

Terblanche, N.S. \& Boshoff, C., 2006, 'The relationship between a satisfactory in-store shopping experience and retailer loyalty', South African Journal of Business Management 37(2), 33.

Turyakira, P., Venter, E. \& Smith, E., 2014, 'The impact of corporate social responsibility factors on the competitiveness of small and medium-sized enterprises', South African Journal of Economic and Management Sciences 17(2), 157-172. https:// doi.org/10.4102/sajems.v17i2.443

Van der Merwe, R. \& van Heerden, G., 2009, 'Finding and utilizing opinion leaders: Social networks and the power of relationships', South African Journal of Business Management 40(3), 65-76.
Van der Post, W.Z., de Coning, T.J. \& Smit, E.v.M., 1997, 'An instrument to measure organizational culture', South African Journal of Business Management 28(4), organization $147-169$.

Van Oordt, T. \& Mulder, I., 2016, 'Implementing basic e-learning tools into an undergraduate taxation curriculum', Meditari Accountancy Research 24(3), 341367. https://doi.org/10.1108/MEDAR-08-2015-0054

Van Rensburg, P., 2001, 'A decomposition of style-based risk on the JSE', Investment Analysts Journal 30(54), 45-60.

Van Rensburg, P., Penn, G. \& Haiden, M., 1998, 'A note on the effect of secondary school accounting study on university accounting performance', South African Journal of Accounting Research 12(1), 93-99. https://doi.org/10.1080/10291954. 1998.11435081

Van Rensburg, P. \& Robertson, M., 2003a, 'Size, price-to-earnings and beta on the JSE securities exchange', Investment Analysts Journal 32(58), 7-16.

Van Rensburg, P. \& Robertson, M., 2003b, 'Style characteristics and the cross-section of JSE returns', Investment Analysts Journal 32(57), 7-15.

Venter, E.R. \& de Villiers, C., 2013, 'The accounting profession's influence on academe: South African evidence', Accounting, Auditing \& Accountability Journal 26(8), 1246-1278. https://doi.org/10.1108/AAAJ-06-2012-01027

Vivian, R. \& Hutcheson, H.-D., 2015, 'Derivation of a framework for annual financial statements of a property-casualty insurance firm: From Adam Smith to the modern insurance firm', South African Journal of Economic and Management Sciences 18(1), 14-31. https://doi.org/10.4102/sajems.v18i1.713

Viviers, H.A., Fouché, J.P. \& Reitsma, G.M. 2016, 'Developing soft skills (also known as pervasive skills): Usefulness of an educational game', Meditari Accountancy Research 24(3), 368-389. https://doi.org/10.1108/MEDAR-07-2015-0045

Ward, M. \& Muller, C., 2012, 'Empirical testing of the CAPM on the JSE', Investment Analysts Journal 41(76), 1-12.

Waweru, N.M. \& Uliana, E., 2005, 'Predictors of management accounting change in South Africa: Evidence from five retail companies', South African Journal of Accounting Research 19(1), 37-71. https://doi.org/10.1080/10291954.2005.11435118

Wessels, P.L., 2008, 'The identification and discussion of strategies for implementing an IT skills framework in the education of professional accountants', South African
Journal of Accounting Research 22(1), 147-181. https://doi.org/10.1080/102919 Journal of Accounting

Wesson, N., Bruwer, B.W. \& Hamman, W.D., 2015, 'Share repurchase and dividend payout behaviour: The South African experience', South African Journal of Business Management 46(3), 43-54.

Willows, G. \& van der Linde, M., 2016, 'Women representation on boards: A South African perspective', Meditari Accountancy Research 24(2), 211-225. https://doi. org/10.1108/MEDAR-01-2016-0001

Wingard, C., Bosman, J. \& Amisi, B., 2016, 'The legitimacy of IFRS: An assessment of the influences on the due process of standard-setting', Meditari Accountancy Research 24(1), 134-156. https://doi.org/10.1108/MEDAR-02-2014-0032

Yoo, T. \& Nam, G., 2015, 'An expanded accounting framework for sustainable growth Focus on the relationship between a focal firm and its stakeholders', South African Journal of Economic and Management Sciences 18(3), 366-379. https://doi. org/10.4102/sajems.v18i3.632

Zaremba, A., 2015, 'Country selection strategies based on value, size and momentum', Investment Analysts Journal 44(3), 171-198. https://doi.org/10.1080/10293523.2 015.1060747

Zhao, Y. \& Lord, B.R., 2016, 'Chinese women in the accounting profession', Meditari Accountancy Research 24(2), 226-245. https://doi.org/10.1108/MEDAR-082015-0058 


\section{Appendix 1}

TABLE 1-A1: Journal overview for five South African accounting journals

\begin{tabular}{|c|c|c|c|c|c|}
\hline Journal name & Year of first issue & Editor & $\begin{array}{l}2015 \text { Scopus citation } \\
\text { statistics } \\
\text { IPP SNIP }\end{array}$ & $\begin{array}{l}\text { Overall h-index } \\
\text { (h-index for } \\
\text { 2012-present) }\end{array}$ & $\begin{array}{l}2016 \mathrm{ABDC} \\
\text { rating }\end{array}$ \\
\hline $\begin{array}{l}\text { Investment Analysts } \\
\text { Journal (IAJ) }\end{array}$ & 1972 & $\begin{array}{l}\text { Christo Auret - } \\
\text { Professor of Finance, } \\
\text { School of Economic and } \\
\text { Business Sciences, } \\
\text { University of the } \\
\text { Witwatersrand, South } \\
\text { Africa }\end{array}$ & 0.8920 .688 & $24(9)$ & $\mathrm{N} / \mathrm{A}$ \\
\hline
\end{tabular}

The Investment Analysts Journal is an international, peer-reviewed journal, publishing high-quality, original research three times a year. The journal publishes significant new reserch in finance and investments and seeks to establish a balance between seeks to establish a balance between theoretical and empirical studies. Papers written in any areas of finance, investment, accounting and economics will be considered for publication. All contributions are welcom but are subject to an objective selection procedure to ensure that published articles answer the criteria of scientific objectivity, importance and replicability.

- Readability and good writing style are important. No articles which have been published or are under review elsewhere will be considered. All submitted manuscripts are subject to initial appraisal by the Editor, and, if found suitable for further consideration, to peer-review by independent, anonymous expert referees. All peer-review is double blind and submission is via email. Accepted papers will then pass through originality papers will then pass through originality right to make the final decision with respect to publication

The Investment Analysts Journal is the official journal of the Investment Analysts Society of South Africa. The Journal is included in the Thomson Reuters Social Science Citation Index and is accredited by the South African Department of Higher Education and Training (DHET).

Charl de Villiers
South African Journal of Business Management

(SAJBM)

South African Journal of conomic and

Managem
970 - based numbers

Eon Smith

Pieter Buys numbers
- Meditari Accountancy Research takes its name from the Latin for constantly pondering, suggesting a journey towards a better understanding of accountancy related matters through research. Innovative and interdisciplinary approaches are encouraged.

- The journal is a double blind refereed publication that welcomes manuscripts using diverse research methods that address a wide range of accountancy related topics, where the terms accountancy and accounting are interpreted broadly. Manuscripts should be interpreted broadly. Manuscrip

Not available online.

The South African Journal of Economic and Management Sciences (SAJEMS) is a leading publication for interdisciplinary research in economic and manaement sciences, with special focus on the African continent. special focus on the African continent. SAJEMS publishes and disseminates academic articles that contribute to the understanding of African markets and the behaviour of economic agents operating in those markets, including consumers, firms and regulators. In addition to applied research on African markets and market participants, the editorial board invites authors to submit interdisciplinary research that breaks down common intellectual silos and prepares a new path for debate on the operation and development of markets in and around Africa.

- SAJEMS is a refereed scientific journal and is accredited by ISI Thomson in their Social accredited by ISI Thomson in their Social African Department of Education. SAJEMS is also indexed and abstracted in EconLit, the also indexed and abstracted in EconLit, Economic Literature (JEL); the relevant JEL Economic Literature (JEL); the relevant
classification number appears with the

classification number a
abstract of each article.

- SAJEMS, which appears in March, June, September and December, is hosted by the Faculty of Economic and Management Sciences at the University of Pretoria. All published articles are assumed to represent the views of the authors; neither the editorial board of the journal nor the University of Pretoria accept responsibility for those views. 
TABLE 1-A1(Continues...): Journal overview for five South African accounting journals

\begin{tabular}{|c|c|c|c|c|c|c|}
\hline Journal name & Year of first issue & Editor & $\begin{array}{l}2015 \text { Scopus citation } \\
\text { statistics } \\
\text { IPP SNIP }\end{array}$ & $\begin{array}{l}\text { Overall h-index } \\
\text { (h-index for } \\
\text { 2012-present) }\end{array}$ & $\begin{array}{l}2016 A B D C \\
\text { rating }\end{array}$ & Aims and scope \\
\hline $\begin{array}{l}\text { South African Journal of } \\
\text { Accounting Research } \\
\text { (SAJAR), formerly known } \\
\text { as De Ratione } \\
\text { (1987-1996) }\end{array}$ & 1987 & Charl Kocks & N/A & $13(4)$ & N/A & $\begin{array}{l}\text { - The South African Journal of Accounting } \\
\text { Research (SAJAR) publishes peer-reviewed } \\
\text { original research papers, notes and } \\
\text { commentaries that address issues relevant to } \\
\text { accounting academics and professional } \\
\text { accountants in Southern Africa and elsewhere. } \\
\text { This includes areas of interest in the study and } \\
\text { practice in financial accounting, auditing, } \\
\text { taxation, financial management, management } \\
\text { accounting, finance, ethics and information } \\
\text { systems. Research papers should be analytical } \\
\text { and contribute to knowledge in the field. They } \\
\text { may be empirically based (including survey } \\
\text { and case study methods) or review and } \\
\text { theoretically based. Notes and commentaries } \\
\text { should meet all the criteria for good quality } \\
\text { research, however their interest and topicality } \\
\text { may compensate for the research problem } \\
\text { being less rigorously pursued. Notes and } \\
\text { commentaries would typically be shorter than } \\
\text { research papers. To provide a balanced } \\
\text { presentation contributions are welcomed } \\
\text { from the fields mentioned above, and from } \\
\text { related areas, such as environmental } \\
\text { accounting, corporate law, corporate } \\
\text { governance, and accounting education. These } \\
\text { fields may be approached from a wide variety } \\
\text { of perspectives such as the behavioural, } \\
\text { technological, institutional, organisational, } \\
\text { regulatory, societal, educational, or } \\
\text { environmental. Manuscripts that pass the } \\
\text { initial screening will be sent for evaluation } \\
\text { based on the double blind peer-review } \\
\text { procedure. }\end{array}$ \\
\hline
\end{tabular}

N/A, not applicable; IPP, impact per publication; SNIP, source normalized impact per paper. 